\title{
ANALISIS STRUKTURAL STIKER DIGITAL LINE POCONG PINKY
}

\author{
Happy Yugo Prasetiya \\ happy.yugo@gmail.com
}

\begin{abstract}
Abstrak
Stiker digital menjadi sarana baru dalam berkomunikasi melalui aplikasi penyampaian pesan. Stiker digital Pocong Pinky menjadi objek material utama karena memiliki konsep visual yang khas tentang kepercayaan mistis di Indonesia. Melalui analisis struktural sebagai pisau bedah, bisa membantu evaluasi terhadap objek material stiker digital. Sehingga stiker digital bisa menjadi sarana komunikasi bersifat visual yang mengandung nilai tertentu di dalamnya. LINE sebagai lembaga penyedia jasa sekaligus produk berperan penting pada perkembangan stiker digital, menjadi bagian yang tak terpisahkan dalam pembahasan. Penelitian ini melalui pengamatan terlibat dalam penggunaan aplikasi LINE dan stiker digital Pocong Pinky. Dari data-data dari objek penelitian, didapat hasil bahwa kreator stiker digital yang memiliki subjektifitas karya terikat aturan-aturan dalam berkarya yang diajukan oleh lembaga penyedia layanan yaitu LINE. Namun yang terpenting gagasan karya kreator pada penelitian ini memberikan perspektif dan nilai baru dalam mengangkat karakter makhluk mistis yang pada awalnya menakutkan bagi masyarakat dikemas dengan lucu, menyenangkan, dan menghibur.
\end{abstract}

Kata kunci : stiker digital line, surface structure, deep structure, pocong pinky

\section{Pendahuluan}

Terlipatnya jarak antar manusia semakin memudahkan setiap orang berkomunikasi dimana pun dia berada, baik itu dengan pesan tertulis, pesan bergambar, suara, hingga video. Dan semua bentuk pesan tersebut, sudah tidak berdiri sendiri melainkan sudah terelaborasi menjadi satu paket dalam aplikasi penyampai pesan di smartphone (telepon pintar). Salah satu jenis aplikasi penyampai pesan tersebut adalah LINE, yang terhitung pada bulan Maret 2016 memiliki pengguna di Indonesia mencapai 60 juta pengguna (Tekno Kompas: 2016).

LINE menyediakan fasilitas berupa stiker digital bagi penggunanya, sebagai pendukung saat mengirim pesan tertulis. Stiker digital ini merupakan varian yang lebih baru dan kaya dibandingkan emoji atau emoticon untuk mengungkapkan ekspresi bergambar saat mengirim pesan tertulis. Dengan berbagai varian karakter kartun LINE yang ditawarkan, memperkaya jenis stiker digital. Perubahan bentuk kata-kata menjadi bentuk visual gambar memberikan arti kesenangan tersendiri bagi pengguna.

Penelitian terkait stiker digital ini masih jarang ditemui dalam bidang keilmuan seni maupun desain komunikasi visual. Dari beberapa jurnal yang ditemukan, konsentrasi bidang keilmuan yang meneliti stiker digital hanya pada wilayah bidang ilmu sosial; yaitu media sosial dan komunikasi. Sedangkan pada bidang ilmu komunikasi, manajemen informasi, dan seni masing-masing ditemukan satu penelitian. Artinya bahwa untuk melakukan penelitian pada objek material berupa stiker digital masih terbuka sangat luas. 
Penelitian pada bidang ilmu sosial yang dilakukan oleh Lim (2015); menemukan bahwa pengguna aplikasi penyampai pesan LINE secara strategis dan dinamis memilih jenis yang terbaik bagi dirinya dari berbagai macam bentuk stiker digital, untuk mengekspresikan emosi, pendapat, serta niat agar komunikasi tetap mengalir. Dan hal ini dititikberatkan pada faktor pengguna, bukan stiker digital.

Pada penelitian bidang keilmuan sosial dan komputer yang dilakukan oleh Wang (2015); penelitiannya dilakukan untuk mempelajari bagaimana efek dari stiker digital LINE yang digunakan oleh pengguna. Meneliti bahwa pesan yang disampaikan melalui gambar berupa ekspresi memberikan penyampaian yang positif dibandingkan emosi yang negatif. Karena melalui ilustrasi tersebut, tersirat perilaku kehidupan nyata berupa humor dan kebahagiaan. Penelitian sosial yang lain dari Stark (2015) meneliti tentang peranan emoji dalam perkembangan lapangan kerja kreatif pada dunia digital. Emoji yang mana saat ini berkembang menjadi bentuk stiker digital memiliki sifat yang hampir sama. Bahwa emoji dirancang secara grafis untuk mewakili bentuk emosional, begitu pula stiker digital.
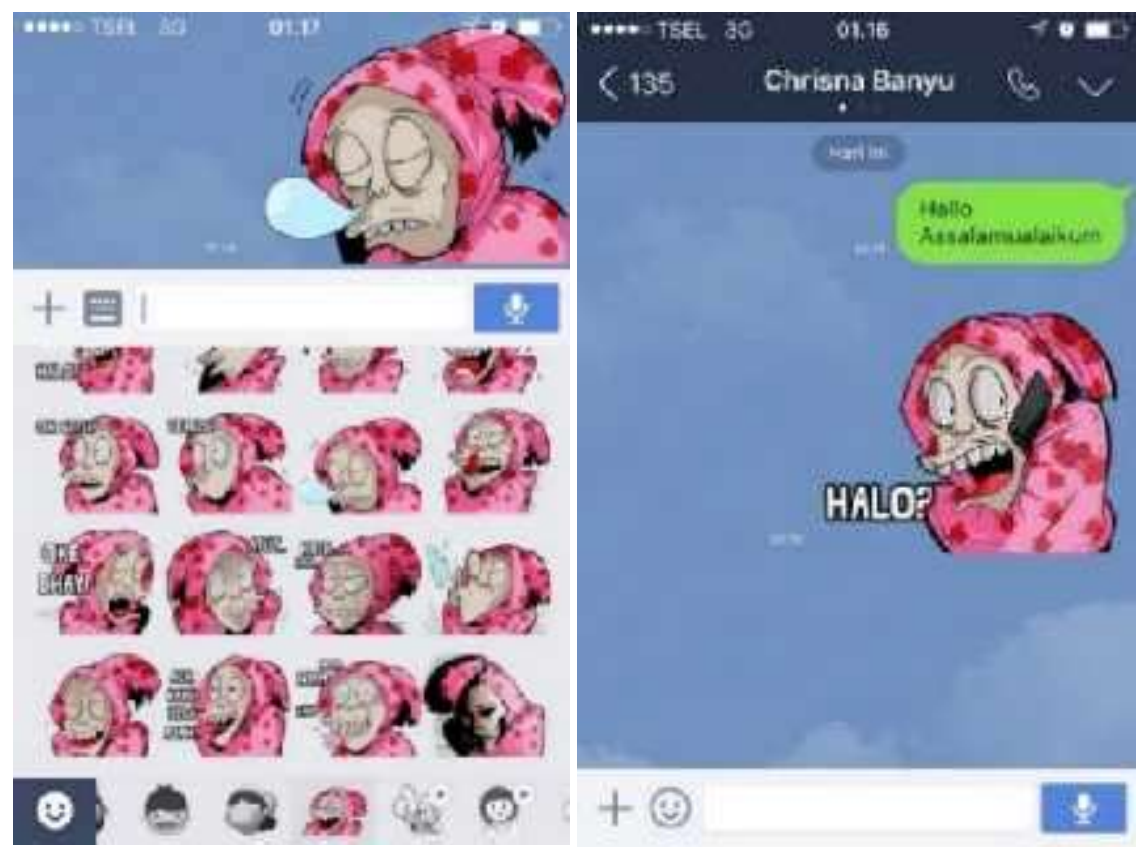

Gambar 1. Contoh penggunaan stiker digital dalam aplikasi percakapan LINE

Selanjutnya, dalam bidang keilmuan manajemen informasi, lebih condong pada analisis intensitas penjualan stiker digital dalam aplikasi LINE (Su: 2015). Dalam Journal Art \& Science, Mahawerawat (2016) menganalisis karakteristik stiker digital LINE yang mempengaruhi keputusan konsumen untuk membelinya. Karakteristik tersebut dibagi menjadi enam : yaitu jenis kelamin, berciri manusia, berciri binatang, kebiasaan, penyertaan teks, dan warna. Di bidang keilmuan komunikasi, penelitian yang dilakukan oleh Cai-wei Peng (2013) menguji dua situasi valensi (positif dan negatif) pada tiga jenis ekspresi inti : teks, stiker, dan stiker dengan teks. Yang menghasilkan stiker dengan tambahan teks memiliki efek keintiman tertinggi, yang kemudian disusul stiker serta teks. 
Dalam uraian tentang penelitian terkait di atas menunjukkan, masih banyak celah yang bisa dimasuki dari objek material stiker digital ini. Dari penelitian sebelumnya, belum ada yang meneliti salah satu sampel dari stiker digital. Meskipun stiker digital yang tersedia di Toko Stiker LINE mencapai ribuan jumlahnya dan pengembang stiker digital tersebut datang dari berbagai negara, hal ini menjadi sangat menarik untuk meneliti salah satu stiker digital. Seperti yang dibuat oleh salah satu kreator stiker Faza Ibnu Ubaidillah, yang melanjutkan kesuksesannya dalam berkomik. Karakter dari karya komik Si Juki yang sudah sukses diangkat ke dalam bentuk stiker digital LINE. Pocong Pinky merupakan salah satu karakter yang ada di komik Si Juki juga diangkat untuk dijadikan stiker digital. Karakter ini berbeda dari karakter-karakter kartun lainnya yang ada di Toko Stiker LINE. Seperti apa karakteristik stiker digital Pocong Pinky? Apakah stiker digital Pocong Pinky ini memiliki nilai arti penting di dalamnya?

\section{Metode Penelitian}

Dalam penelitian ini, data yang digunakan merupakan data dari studi literatur baik artikel jurnal pada pangkal data ProQuest. Artikel jurnal yang sebagai acuan berhubungan dengan topik utama tentang stiker digital. Sehingga kata kunci "stiker digital" digunakan untuk mencari artikel-artikel terkait. Dan didapat enam artikel yang berhubungan dengan stiker digital dalam kurun waktu penerbitan antara tahun 2013 hingga 2016.

Penelitian ini dilakukan melalui pengamatan langsung melalui media sosial dengan keterlibatan langsung menggunakan aplikasi serta menggunakan stiker digital yang menjadi objek kajian. Selain itu, penelusuran terhadap perkembangan aplikasi LINE melalui berita yang diterbitkan oleh media massa online yang terpercaya. Pencarian artikel dari pangkal data serta pengamatan terhadap objek ini dimulai pada bulan Juni hingga September 2016.

Sebagai pisau bedah objek kajian stiker digital Pocong Pinky, digunakan analisis struktural; merupakan model yang dibuat untuk memahami atau menjelaskan gejala kebudayaan yang dianalisis. Model ini ini merupakan relasi-relasi yang saling berhubungan dan saling mempengaruhi disebut sebagai system of relations (Lévi-Strauss: 1963). Dalam melakukan analisis struktural dibedakan menjadi dua jenis struktur, yaitu surface structure dan deep structure.

Heddy Shri Ahimsa-Putra (2013) dalam bukunya berjudul 'Strukturalisme LéviStrauss, Mitos dan Karya Sastra' menjelaskan bahwa surface structure ini adalah relasirelasi antar unsur yang dapat dibuat atau dibangun berdasarkan ciri-ciri luar (empiris) dari relasi-relasi tersebut. Surface structure berupa struktur luar yang bersifat seperti apa yang dilihat wujudnya. Sehingga stiker digital bisa dianalisis dari struktur luarnya (surface structure) berupa bentuk visualnya, seperti apa bentuk objek material yang diidentifikasi secara empiris.

Sedangkan deep structure itu sendiri merupakan struktur dalam dari objek material, berupa susunan tertentu yang dibangun berdasarkan atas struktur lahir yang tidak selalu tampak secara empiris dari fenomena yang ada. Pada stiker digital ini digali lebih dalam mengenai deep structure yang terkandung di dalamnya. Manfaat yang bisa diambil bagi desainer grafis adalah ketika membuat sebuah desain stiker digital tentunya, jangan hanya 
menunjukkan sekedar gambar saja, tapi juga bisa mengandung makna di dalamnya. Tentunya konsepsi sebuah desain diperlukan pematangan yang lebih mendalam.

Dalam penganalisaan surface structure dan deep structure ini akan dipaparkan terlebih dahulu deskripsi mengenai objek kajian berupa stiker digital Pocong Pinky atau hal-hal yang berkaitan yang bersifat empiris. Sehingga nanti ditemukan gambaran umum dari objek kajian yang menunjukkan struktur luar objek dalam bentuk deskriptif naratif. Selanjutnya, untuk memperjelas makna, dilanjutkan dengan pembahasan deep structure yang berupaya menggali lebih dalam nilai yang terkandung dalam stiker digital Pocong Pinky

\section{Surface Structure Objek Kajian Stiker Digital Pocong Pinky}

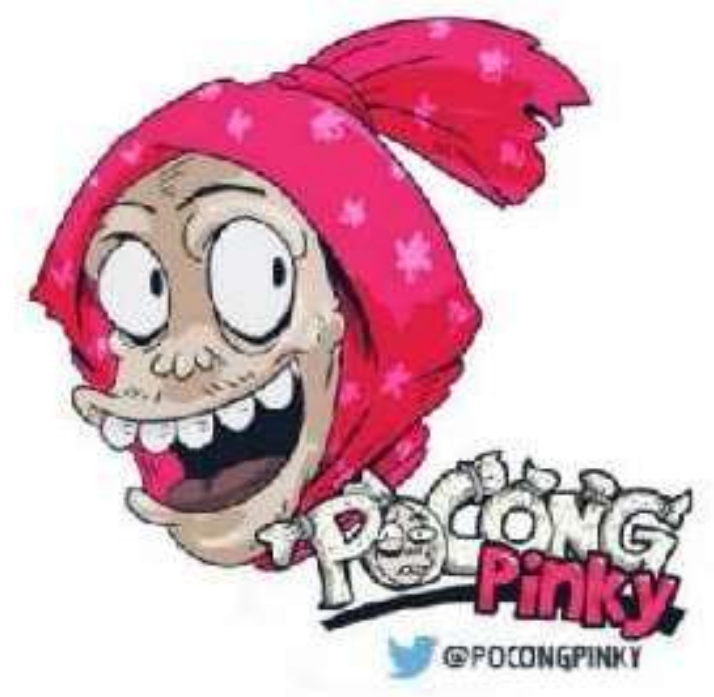

Gambar 2. Karakter dan logo Pocong Pinky di komik (Sumber: webtoons.com)

Karakter Pocong Pinky ini memiliki panggilan bernama "Congky", singkatan nama dari Pocong Pinky itu sendiri. Karakter Congky ini diciptakan oleh penulis dan ilustrator komik Faza Meonk yang memiliki nama lengkap Faza Ibnu Ubaydillah Salman. Keunikan yang paling terlihat adalah pocong ini tidak menggunakan kain putih melainkan kain warna pink (merah jambu).

Kemunculan Pocong Pinky ini dimulai dalam cerita Si Juki episode 14 versi Webtoon, yang mana di dalam cerita, Pocong Pinky ini ingin menakut-nakuti Si Juki namun gagal dikarenakan Pocong Pinky berpenampilan serba pink (merah jambu). Kemudian Congky dan Si Juki menjadi sahabat dan dalam cerita komik Si Juki, Congky ini muncul di dalam komik tersebut di beberapa episode.

Setelah kemunculan Congky di komik Si Juki yang mendapat respon positif dari pembaca, Congky keluar dalam versi komik tersendiri berjudul "Pocong Pinky" bergenre komedi. Dari kisahnya sendiri ini diceritakan asal mula kenapa Congky bisa menggunakan kain berwarna merah jambu pada saat dikuburkan. 
Dalam cerita awal nama asli Congky adalah Jono seorang pemuda pengangguran yang sedang patah hati, dia mengalami kecelakaan tertabrak truk. Setelah dipastikan tewas, untuk menghilangkan jejak oleh pengemudi truk dimakamkan secara ala kadarnya, dan kebetulan kain kafan yang ada sudah habis.

Sehingga mau tak mau si sopir truk menggunakan kain merah jambu bermotif bunga-bunga untuk menguburkan Jono.

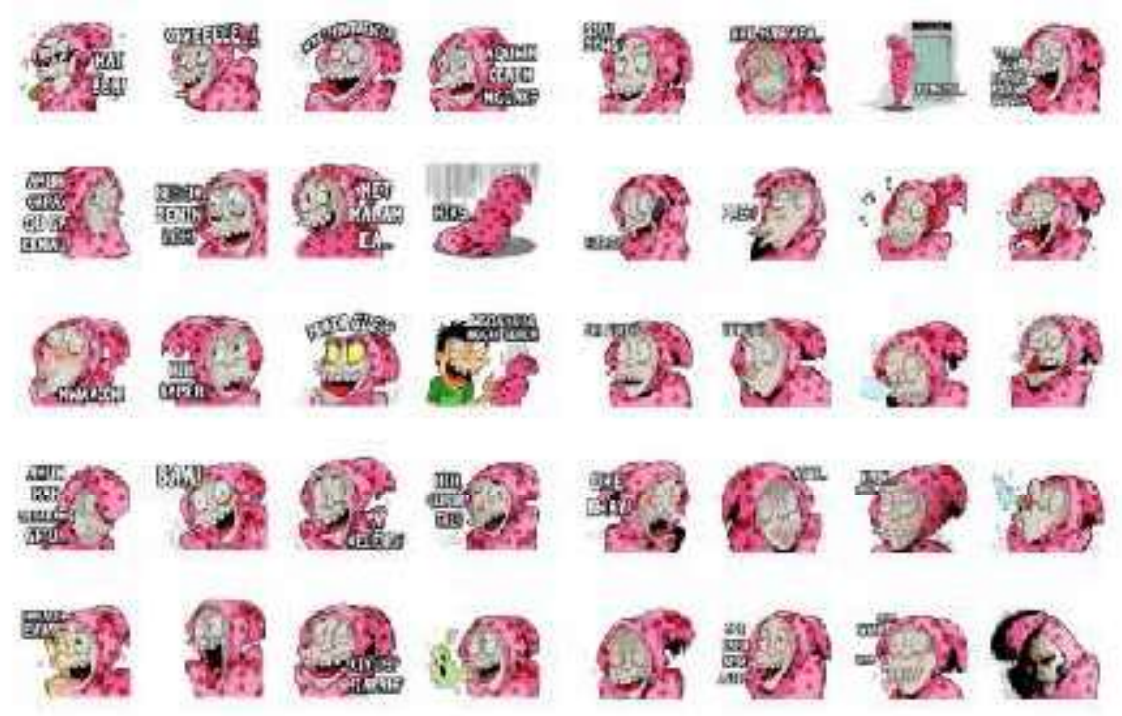

Gambar 3. Ekspresi karakter Pocong Pinky di stiker digital LINE (Sumber: store.LINE.me)

Penampilan Congky secara umum sebenarnya sama seperti pocong pada umumnya. Seluruh tubuh terbungkus kain yang menyisakan bagian wajah saja. Yang membedakan adalah warna kain yang berwarna merah jambu dengan motif bunga-bunga. Gaya gambar Faza pada Pocong Pinky masih seperti gaya penggambaran Si Juki. Bersifat kartun dengan pola bentuk yang sangat sederhana namun sangat ekspresif.

Pengunaan outline pada karakter ini memiliki bentuk garis hitam kombinasi antara tebal dan tipis. Kreator sudah memahami bagian mana yang seharusnya menggunakan garis tebal dan garis tipis. Pemilihan warna tergolong sederhana dengan tampilan empat warna dasar, yang masing-masing dikombinasikan dengan warna shadow yang lebih gelap. Sehingga kesan yang ditimbulkan tidak terlihat flat, namun memiliki bentuk fisik yang seakan solid dan berbentuk. Wajah yang terlihat menunjukkan bahwa karakter Pocong Pinky ini tonggos.

Seperti halnya pada karakter Si Juki yang juga sama-sama tonggos. Memperlihatkan susunan gigi yang renggang, sehingga terlihat bahwa karakter ini memiliki sifat yang lucu seperti halnya di komik yang bergenre komedi. 

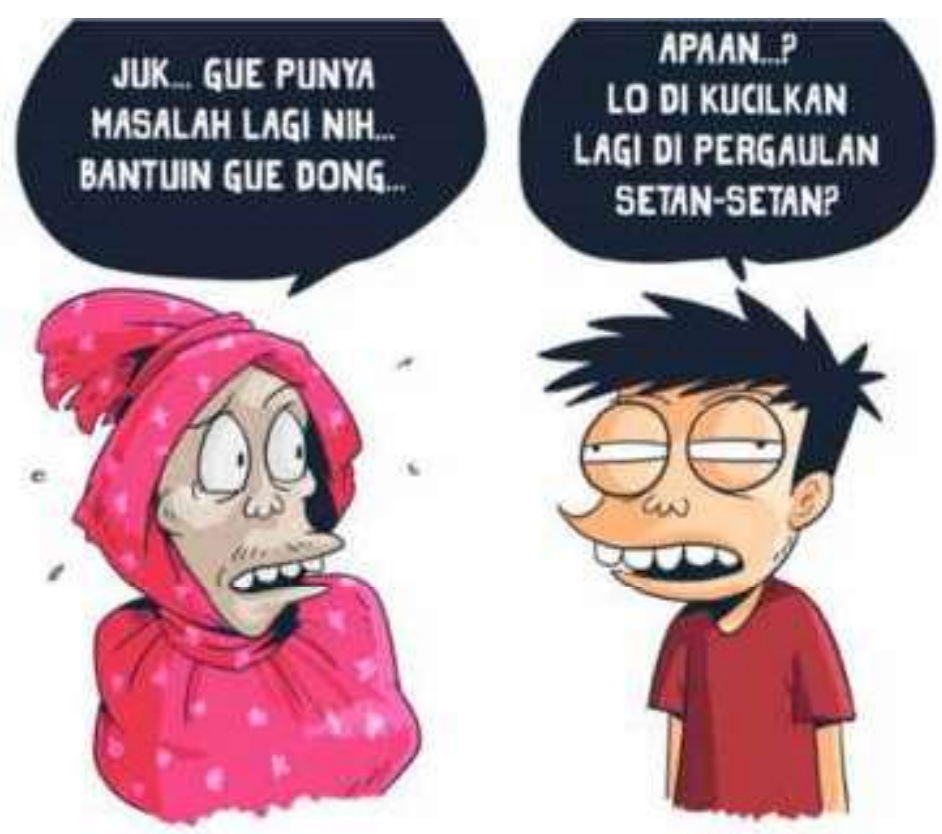

Gambar 4. Karakter Pocong Pinky dan Si Juki dalam serial komik Webtoon (Sumber: webtoons.com)

Jumlah stiker yang tersedia dalam paket stiker Pocong Pinky berjumlah 40 stiker digital. Dengan berbagai macam ekspresi atau emosi. Dari ekspresi senang, sedih, takut, bingung, malu, sinis, ejekan atau sindiran, dan sapaan. Lalu untuk penggambaran Congky ini dalam stiker digital sendiri rata-rata tampil secara close up.

Dari 40 buah stiker hanya dua stiker saja yang menampilkan Pocong Pinky seluruh badan. Serta penggunaan kata atau kalimat digunakan di 31 display stiker Pocong Pinky ini, sembilan stiker sisanya hanya tampil menggunakan visual ekspresi saja tanpa tambahan kata. Serta dalam satu stiker disisipkan karakter Si Juki, ditampilkan dengan ekspresi yang sedang mengejek Congky.

\section{Deep Structure Objek Kajian Stiker Digital Pocong Pinky}

Penganalisaan ini melibatkan tiga unsur, pertama adalah kategori kebudayaan, untuk menunjukkan posisi objek kajian termasuk dalam kategori kebudayaan seperti apa. Selanjutnya yang kedua adalah pelembagaan, penjabaran konteks lembaga yang memunculkan objek tersebut menyebar di masyarakat. Ketiga adalah simbol, makna apa yang terkandung dalam objek kajian.

\section{Kategori Kebudayaan}

Dalam teori kebudayaan yang digagas oleh Koentjaraningrat, kebudayaan memilki tujuh unsur sebagai isi pokok dari tiap kebudayaan yang ada di dunia. Tujuh unsur kebudayaan tersebut antara lain; bahasa, sistem pengetahuan, organisasi sosial, sistem peralatan hidup 
dan teknologi, sistem mata pencaharian hidup, sistem religi, dan kesenian (Koentjoroningrat, $165: 2009$ ).

Dari tujuh unsur kebudayaan tersebut di manakah posisi dari stiker digital ini? Tentunya posisi objek stiker digital tidak terpaku pada salah satu unsur kebudayaan tersebut, namun berelasi dengan beberapa unsur kebudayaan yang ada.

Kemunculan awal dari stiker digital ini telah dijelaskan di awal bahwa perkembangan teknologi komunikasi yang berkembang. Sehingga bisa dikatakan bahwa unsur kebudayaan berupa sistem teknologi manusia memberikan pemantik atas kemunculan stiker digital.

Telepon genggam pintar yang disebut sebagai smartphone merupakan hasil dari teknologi manusia, beserta perangkat lunak yang ada di dalamnya untuk menjalankan program sehingga telepon genggam tersebut bisa dipergunakan dengan segala kecanggihannya. LINE merupakan perangkat lunak dari sekian banyak pilihan perangkat lunak penyampai pesan yang ditawarkan di dalam smartphone. LINE sebagai produk teknologi ciptaan manusia memberikan fitur di dalamnya berupa stiker digital, untuk memberikan pilihan bagi pengguna dalam berkomunikasi lewat penyampai pesan secara digital.

Komunikasi menjadi kata kunci kedua, dalam unsur kebudayaan komunikasi muncul dalam unsur bahasa. Karena bahasa itu sendiri adalah bentuk komunikasi antar manusia. Dalam stiker digital ini bukan lagi bahasa berupa tulisan yang diungkapkan melainkan berupa imaji atau gambar digital. Pengguna LINE bisa menunjukkan ekspresinya dalam percakapan tertulis dengan menampilkan bentuk stiker digital berupa gambar yang sesuai ekspresi yang ingin dia tunjukkan saat itu. Bentuk stiker digital pun muncul dengan berbagai bentuk rupa dan warna. Tentunya dalam pembuatannya dibutuhkan jiwa yang artistik untuk menghasilkan bentuk stiker digital yang menarik bagi para penggunanya.

Di sinilah unsur kebudayaan berupa seni dan desain ini berperan, bagaimana menciptakan kumpulan stiker digital yang memiliki tampilan yang estetik dan nilai jual bagi pengguna. Teknologi juga berperan dalam perkembangan unsur kesenian ini, yang di mana dalam pembuatan stiker digital ini juga mengandalkan peralatan digital berupa komputer beserta peralatan pendukungnya. Karena pengaplikasian stiker digital ini pada akhirnya dimunculkan dalam bentuk digital. Seniman sendiri bisa saja menggambarkannya dengan bentuk manual tapi pada akhirnya mau tak mau seniman tersebut harus mengubah dari bentuk gambar yang ada di kertas menjadi berupa data digital melalui proses scanning. Seniman sendiri akan memiliki sebutan baru bagi yang bergelut di bidang seni digital sebagai digital artist (seniman digital).

Sebagai sebuah mata pencaharian, pembuat stiker digital bisa memiliki pendapatan tersendiri dalam kreasi stiker yang telah dia buat. Si seniman bisa memperoleh pendapatan dari stiker yang dia buat melalui penjualan yang dilakukan di LINE Store, toko stiker digital yang disediakan LINE untuk para pembuat stiker digital yang ingin menjual stiker hasil buatannya, dan para pengguna LINE reguler yang ingin membeli stiker digital. Pertemuan antara penjual dan pembeli dalam ruang yang diciptakan oleh LINE ini merupakan sebuah bentuk pengorganisasian sosial dalam dunia digital.

LINE berperan sebagai penyedia ruang untuk mempertemukan berbagai pengguna baik untuk berkomunikasi, bertukar informasi, bermain permainan digital, hingga jual 
beli. Sehingga ini merupakan sebuah bentuk dari unsur kebudayaan berupa sistem organisasi sosial. Di mana setiap orang dipertemukan melalui jaringan digital yang LINE sediakan. LINE memberikan aturan-aturan tertentu dalam proses jual-beli stiker. Sampai LINE sendiri menyediakan mata uang khusus bagi pengguna LINE yang ingin membeli berbagai fitur digital yang disediakan LINE termasuk stiker digital.

Secara umum yang terkandung dalam stiker digital terdapat lima unsur kebudayaan yang dipaparkan oleh Koentjaraningrat. Namun secara spesifik dalam kasus stiker digital Pocong Pinky terdapat hubungan dengan unsur kebudayaan berupa sistem religi. Hubungan keduanya merupakan sebuah bentuk respon dari stiker digital Pocong Pinky terhadap kepercayaan mistis yang terbangun dalam masyarakat tradisi. Dalam agama Islam seseorang yang sudah meninggal dunia harus dimakamkan dengan tata cara khusus. Caranya dengan membungkus jenazah menggunakan kain putih yang menyelimuti seluruh bagian tubuhnya kecuali wajahnya. Tali yang mengikat kain dengan tubuh jenazah harus dilepaskan saat dikuburkan. Terdapat kepercayaan jika tali tersebut tidak dilepas maka arwah jenazah tersebut akan bangkit menjadi makhluk gaib yang disebut dengan pocong. Dari unsur religi inilah stiker Pocong Pinky merespon dengan bentuk atau kemasan yang berbeda dengan wujud pocong yang dipercayai oleh masyarakat pada umumnya. Bahwa makhluk gaib bernama pocong yang mengerikan bagi masyarakat ini bisa tampil dengan lucu dan konyol.

Sebagai produk yang dihasilkan dari perkembangan teknologi, stiker digital muncul karena kebutuhan dasar manusia akan komunikasi. Meskipun bukan hal yang paling mendasar stiker digital hadir menjadi pelengkap luapan emosi bagi pengguna produkproduk teknologi digital. Di mana seni visual diterapkan dalam sebuah produk komunikasi digital yang secara langsung pula merefleksikan ekspresi pengguna secara instan dan itu sah dalam pengertian kebudayaan postmodern.

Dalam buku Postmodernisme Tantangan Bagi Filsafat, Sugiharto mengasosiasikannya dengan seni menunjukkan bahwa dalam era postmodern menghilangkan batasan antara seni dan kehidupan sehari-hari, tumbangnya antara budaya tinggi dan budaya pop, mencampurkan gaya yang bersifat eklektik, parodi, pastiche, ironi, kebermainan dan merayakan budaya "permukaan" tanpa peduli "kedalaman", hilangnya orisinalitas dan kejeniusan, dan akhirnya sampai pada asumsi bahwa seni hanya mengulang-ulang masa lalu saja (Sugiharto, 26: 1996). Ketika kita melihat gejala postmodern seperti halnya yang dikatakan Sugiharto tersebut mari ditarik garis ke depan pembahasan teks stiker digital yang juga mengalami hal yang serupa.

Mengadaptasi bentuk budaya tradisional berupa pocong kemudian ditransformasikan ke dalam bentuk seni visual yang berfungsi sebagai komponen komunikasi digital. Hal ini menunjukkan penggabungan dua budaya tradisi dan budaya digital yang bersintesis menjadi sebuah karya parodi. Ketika diperhatikan lagi secara seksama mengenai sifatsifat yang terkandung dalam stiker digital tersebut mencampuradukkan budaya tradisi dengan kemasan parodi dan seni pop. Dan ini juga bisa kita lihat wujud dari stiker digital yang muncul dengan parodi-parodi emosi pengguna.

Namun yang menjadi pertanyaan lagi adalah jika postmodern ini tidak peduli dengan kedalaman dan hanya struktur dalamnya saja atau bersifat banal. Maka hal tersebut mesti dikaji ulang lagi. Tidak semua karya postmodern bersifat permukaan saja. Pembuktiannya 
adalah dari sisi perubahan stigma yang coba dibuat oleh para kreator stiker digital Pocong ini. Pocong yang dalam masyarakat tradisi dianggap sebagai makhluk halus yang bisa dikatakan menakutkan, dihadirkan kembali oleh para kreator stiker digital dalam wujud parodi. Ini bertujuan untuk membangun stigma baru kepada masyarakat untuk melihat sosok hantu pocong ini dari sisi lain. Dan hal tersebut sangat membantu pengguna pada sisi hiburan dalam berkomunikasi.

\section{Pelembagaan}

Dalam praktik sistem digital bersifat online memerlukan campur tangan pelembagaan yang bisa mengatur penggunaan media digital. Seperti halnya mengatur lalu-lintas jalan sistem digital online juga memerlukan pengaturan lalu lintas data agar sistem tetap berjalan lancar. Tentunya pelembagaan ini berbentuk korporasi swasta dan dalam hal ini LINE berperan dalam masalah pengaturan lalu-lintas data.

Begitu pula untuk persoalan penilaian layak tidaknya stiker digital sudah diatur sesuai peraturan yang ditentukan oleh LINE dan harus dipatuhi oleh kreator yang bekerja secara profesional. Aturan-aturan yang dilakukan LINE memberikan jalan agar para kreator tidak sembarangan membuat produk stiker yang nantinya merugikan pihak lain. Dari sisi tema stiker hingga hal teknis pembuatan stiker sudah diatur secara detail oleh pihak LINE.

LINE juga berperan sebagai moderat, yang menjembatani pengenalan budaya asing dan lokal supaya bisa membaur dan mengkomparasi setiap nilai lokal dengan asing. Karena dalam penggunaan media aplikasi mobile LINE ini melibatkan bermacam pengguna yang berasal dari berbagai negara dan kebudayaan. 216 juta pengguna LINE merupakan jumlah yang tidak sedikit (id.techinasia.com). Dengan jumlah seperti itu sudah mendekati jumlah penduduk negara Indonesia. Dan sudah melewati jumlah batas jumlah penduduk negara lain malahan. Tentunya fenomena ini tidak bisa dianggap sesuatu yang dangkal namun sesuatu yang besar dengan berbagai macam peluang dan kemungkinan yang bisa dilakukan di dalam satu aplikasi mobile ini.

LINE juga mengakomodir sistem penjualan stiker yang memberi pengaruh terhadap sistem ekonomi berbasis digital. Pengguna yang ingin menggunakan stiker tersebut harus membayar dengan Coin LINE dengan membayarnya menggunakan pulsa ataupun kartu kredit. Sistem pembayaran ini secara tidak langsung memberikan dampak dalam sebuah sistem ekonomi di mana pemanfaatan media sosial berbasis perangkat mobile. Sehingga bisa terlihat bagaimana peran LINE sebagai pelembagaan sangat berpengaruh dalam berbagai aspek.

Tentunya eksistensi sebuah stiker digital ditopang oleh sebuah sistem yang dibangun oleh lembaga swasta berbasis teknologi. Muncul atas kebutuhan pengguna yang menginginkan tidak hanya kemudahan berkomunikasi melainkan juga faktor hiburan sebagai pelengkap kemudahan berkomunikasi. 


\section{Simbol}

Mengutip apa yang dikatakan Suzanne K. Langer dalam buku "Problematika Seni” yang menyatakan bahwa; karya seni merupakan objektifikasi dari kehidupan subjektif (Langer,10: 2006). Sehingga bila dijabarkan mengenai apa yang Langer nyatakan tersebut, setiap karya seni khususnya seni visual terapan seperti ini mempresentasikan berupa objek seni yang di dalamnya terkandung subjektifitas penciptanya, tentunya ini juga masuk karena adanya pengaruh-pengaruh luar yang menyatu dengan pengalaman seninya.

Simbol tidak terlepas dari makna ekspresi yang dari sebuah karya, terutama simbol yang muncul dalam sebuah karya visual stiker digital ini. Tentunya sangat mewakili simbol-simbol ekspresi yang ditawarkan oleh kreatornya kepada pengguna. Dan selanjutnya pengguna juga memilih simbol ekspresi yang bisa mewakili dirinya, artinya memilih stiker yang dia suka.

Dan yang menarik pada pembahasan ini adalah simbol perlawanan terhadap kepercayaan mistik tradisional oleh subjek yang membuat stiker digital. Dalam karya Faza berupa Pocong Pinky sangat-sangat bertolak belakang dengan makna representasi pocong itu sendiri. Bisa dikatakan hal semacam ini bentuk ekspresi pribadi dari kreator dalam menyikapi atau memandang sebuah fenomena di masyarakat. Sehingga apa yang dia lawan di sini sebenarnya adalah ketakutan akan sosok pocong itu sendiri yang sudah merasuki urat kehidupan masyarakat dengan cara menyajikan sosok pocong dengan konsep baru berwarna pink/merah jambu. Dan untuk menambah pola parodi dalam karakter ini dimunculkan juga pattern atau pola bunga-bunga dalam kain pink pocong tersebut.

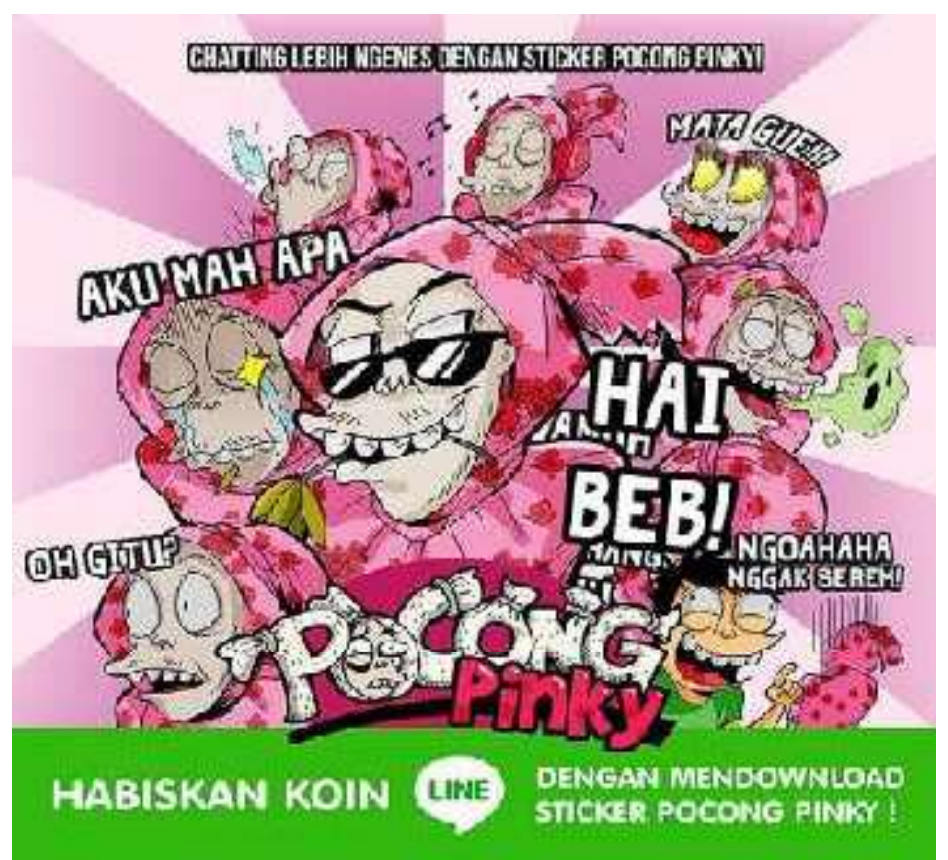

Gambar 5: Iklan web mobile, karakter stiker Pocong Pink yang bertolak belakang dengan wujud ideal Pocong

(Sumber: store.LINE.me) 
Pengguna aplikasi mobile LINE yang mengunduh stiker Pocong Pink ini diajak untuk melihat kembali konstruksi baru tentang wujud konsep Pocong yang bisa ditertawakan dan dikasihani dengan tampilan visual yang menggemaskan, satir dan lucu. Sebuah wujud visual yang membuat pengguna berpikir ulang tentang makna ketakutan dari sosok makhluk gaib.

Penggunaan tambahan tulisan berupa kata dan kalimat menunjukkan adanya keterbatasan bahasa visual yang digunakan pada stiker digital Pocong Pinky ini. Seakanakan simbol visual berupa gambar yang ekspresif tidak cukup untuk menjelaskan makna yang dimaksudkan oleh si kreator stiker. Ada dua kemungkinan yang terjadi kenapa selalu ditampilkan teks dalam stiker ini, pertama adalah faktor yang berasal dari kreator stiker digital yang ingin memperkuat ekspresi dari gambar yang kurang komunikatif dengan tambahan teks.

Keterbatasan bentuk pocong memberikan dampak pada pola gestur yang juga ikut terbatasi. Sehingga penguatan dilakukan pada ekspresi wajah karakter Pocong Pinky. Kedua adalah faktor pengguna; pengguna dari stiker digital tidak bisa sepaham mengartikan makna atau arti dari gambar ekspresi wajah stiker digital Pocong Pinky. Sehingga merasa perlu untuk menambahkan teks (tulisan) yang memperjelas arti dari ekspresi tersebut.

\section{Kesimpulan}

Objek kajian stiker digital menunjukkan keterkaitan antara permukaan luar dengan permukaan dalam. Tentunya pengaruh budaya masih melekat erat pada perkembangan teknologi saat ini. Meskipun hanya tampil dengan bentuk visual representasi budaya tradisional bertransformasi menjadi nilai yang lebih baru. Berbagai macam perubahan dilatarbelakangi oleh sosok kreator yang berperan sebagai subjek yang mengekspresikan sisi pengetahuan dan pengalamannya untuk dibagi kepada pengguna. Yang kemudian berpengaruh terhadap tindakan-tindakan pengguna dari responnya terhadap karya stiker digital yang mereka gunakan.

Sebagai objek kajian, stiker digital Pocong Pinky memiliki surface structure berupa elemen visual yang berupa gaya gambar dari si kreator. Subjektifitas kreator sangat terlihat jelas pada gaya gambar karakter stiker digital. Hal itu bisa dilihat dari gaya gambarnya yang sangat ekspresif dan memiliki kesamaan dengan karyanya yang sebelumnya. Cara penerapan garis pada gambar stiker digital menunjukkan gaya gambar yang ekspresif dengan tarikan garis tebal tipis yang kadang tak beraturan. Serta penggunaan warna yang sederhana tapi memiliki kesan kedalaman sebuah benda menunjukkan kapabilitas si kreator ini. Kreator sendiri terikat secara langsung dengan lembaga terkait yaitu LINE, di mana kreator harus mematuhi aturan-aturan teknis maupun nonteknis yang diajukan oleh LINE.

LINE sebagai lembaga sudah menjadi wadah berkumpulnya berbagai macam pengguna yang tersebar di seluruh dunia. Imbas yang terjadi pada stiker digital itu sendiri membuatnya harus bisa memenuhi syarat yang diberikan LINE untuk bisa mengisi 
kebutuhan pengguna. Pengelola LINE di tiap negara menerapkan spesifikasi khusus pada pengguna LINE di setiap negaranya.

Stiker Pocong Pinky sendiri mengkhususkan diri pada pengguna di Indonesia, karena kemungkinan besar pasar di luar Indonesia tidak memahami apa itu pocong, serta jargonjargon gaul yang diusung dalam bahasa Indonesia tidak mungkin bisa dipahami oleh orang di luar negeri. Seharusnya keberadaan stiker yang sudah terpasang di etalase maya tersebut bisa menunjukkan budaya Indonesia kepada dunia, dan ini peluang yang belum dimanfaatkan sepenuhnya oleh kreator.

Segmentasi yang dilakukan oleh Pocong Pinky dilakukan dalam bentuk penggunaan kata-kata berbahasa Indonesia dalam stikernya. Hanya untuk mengejar pangsa pasar yang berasal dari Indonesia saja. Sehingga penggunaan bentuk kata atau kalimat dalam stiker malah menunjukkan ekspresi yang terkesan instan diberikan untuk pengguna yang memang ternyata belum bisa memahami makna arti sebuah ekspresi dalam bentuk visual gambar.

Penambahan teks hanya untuk bisa menunjukkan ekspresi yang diinginkan.

Selayaknya stiker digital Pocong Pinky memiliki kekuatan di sisi visual, tanpa keterangan kata atau kalimat semua orang bisa memahaminya. Meskipun dalam keterbatasan wujud pocong yang minim gestur, hendaknya bisa dieksplorasi lagi untuk menemukan gestur yang cocok sesuai bentuk visualnya.

Perubahan nilai dari pocong yang secara tradisi mistis merupakan wujud yang menyeramkan dan menakutkan, ternyata pada stiker digital Pocong Pinky ini bisa dielaborasikan menjadi sebuah karya stiker yang lucu, satir, dan menghibur.

\section{Kepustakaan}

Ahimsa-Putra, Heddy Shri. 2013. "Strukturalisme Lévi-Strauss, Mitos dan Karya Sastra”. Yogyakarta: Kepel Press

Koentjaraningrat. 2009. "Pengantar Ilmu Antropologi (Edisi Revisi 2009)”. Jakarta: Penerbit Rineka Cipta

Langer, Suzanne K. 2006. "Problematika Seni”. Terjemahan FX. Widaryanto, Bandung: Sunan Ambu Press

Lévi-Strauss. 1963." Structural Antrophology”. New York: Basic Books

Lim, Sun Sun. 2015. "On Stickers and Communicative Fluidity in Social Media". Social Media + Society Vol 1.SAGE journals.

Mahawerawat, Nattaporn., and Khamwon, Anon. 2016. "Characteristics Of Sticker LINE, Electronic Word Of Mouth, And Intention To Buy". Conference of the Internasional Journal of Arts \& Science.09(01), 275-280.

Peng, Cai-wei. 2015. "Is a Sticker Worth a Thousand Words? The Intimacy Effect of Stickers in Mobile Messaging Application LINE". [Thesis]. Taiwan: Departement of Communications Management, National Sun Yat-sen University.

Stark, Luke. 2015. "The Conservatism of Emoji: Work, Affect, and Communication". Social Media + Society Vol 1.SAGE journals.

$\mathrm{Su}$, Yu-Ting. 2015. "A Study on In-App Purchase Intention of Emotion Stickers for Messaging Software- The Case of LINE". [Thesis]. Taiwan: Departement of Information Management, National Sun Yat-sen University.

Sugiharto, Bambang. 1996. "Postmodernisme: Tantangan bagi Filsafat". Yogyakarta: Penerbit PT Kanisius 
Wang, Shaojung Sharon. 2015. "More Than Words? The Effect of LINE Character Sticker Use on Intimacy in the Mobile Communication Environment". Social Science Computer Review. Vol. 34 no. 4 456-478. SAGE journals.

Faza Meonk. Pocong Pinky. (diakses pada: 21 Juni 2016) Alamat website: https://ngomik.com/comic/6544-pocong-pinky

Faza Meonk. Si Juki Lika Liku Anak Kos, Episode: 14. (diakses pada: 21 Juni 2016) Alamat website: http://www.webtoons.com/id/comedy/sijuki/ep14/viewer?title_no=447\&episode_no $=15$

Faza Meonk. Pocong Pinky. (diakses pada: 21 Juni 2016) Alamat website: https://store.LINE.me/stickershop/product/1205025/id

Tekno Kompas. Deliusno. (diposting pada: 24 Maret 2016) "Indonesia” Berkali-kali Disebut di Hajatan Akbar LINE. Tekno Kompas. (diakses pada: 10 Juli 2016) Alamat website: http://tekno.kompas.com/read/2016/03/24/17340047/.Indonesia.Berkalikali.Disebut.di.Hajatan.Akbar.LINE 